\title{
Optimization of insecticidal potency of composites of aqueous, acetone, and ethanol extracts of Piper guineense seed on Callosobruchus maculatus by the simplex-lattice mixture experimental design.
}

\section{Ojimelukwe Phillippa ${ }^{1}$, Udofia, Patrick $\mathrm{G}^{2 *}$, Anthony Ukom ${ }^{1}$,Ukpe. Richard ${ }^{3}$}

${ }^{1}$ Department of Food Science and Technology, Michael Okpara University of Agriculture, Umudike, P. M. B. 7267, Abia State, Nigeria

${ }^{2}$ Department of Food Science and Technology, Michael Okpara University of Agriculture, Umudike, P. M. B. 7267, Umuahia. Abia State, Nigeria

${ }^{4}$ Department of Chemistry, Federal University, Otueke, Bayelsa State.

${ }^{3}$ Department of Food Technology, Akwa Ibom State Polytechnic, Ikot Osurua, P. M. B. 1200, Ikot Ekpene, Nigeria.

*Corresponding authors: email: kesitpatrick1@gmail.com,

Abstract- The objective of this study was to investigate the effect of composites of extracts of Piper guineense seed on Callosobruchus maculatus using the mixture experimental design of the response surface methodology (RSM).Callosobruchus maculatus damages stored legumes and grains resulting in huge agronomic and economic losses. Synthetic chemical insecticides is currently in useto check the wastage despite their known toxicity to man and the environment. Efforts to find alternatives to chemical synthetic insecticides has spotted Piper guineenseas a promising alternative candidate but less work has been done on its preparation and formulation for optimum activity. Fresh Piper guineenseberry was harvested from Essien Udim Local Government Area, of Akwa Ibom State, it was dried in the sun to moisture content of about $14 \%$ and ground to pass through 100 mesh sieve. The ground seed was extracted with ethanol and concentrated to obtain a slurry. Single blends of aqueous, ethanolic, acetone extracts of Piper guineense seed showed increasing insecticidal potency on the testinsect than binary blends.The model of dead insect was significant $\left(R^{2}=0.9931\right.$, Mean=68.69), bean damage was significant $\left(R^{2}=09786\right.$, Mean 63.46). Optimization analysis of experimental data revealed that 0.09, 0.437, 0.473 proportions of aqueous, ethanolic, and acetone extracts of Piper guineense seed respectively produced $95 \%$ and $31 \%$ dead insects and bean damage respectively at a desirability level of $76.80 \%$.Result of the study shows that composites extracts of Piper guineense seeds could be a useful controller of stored maize.
Keywords- Mixture experimental design, blends, Callosobruchus maculatus, PiperguineenseSchum. Et.Thonn.

\section{INTRODUCTION}

Callosobruchus maculatus infestation is a major contributor to qualities deterioration of stored cowpea, (Vigna anguiculata), 'black eye'. According to [1], the insect infestation causes considerable physical and nutritional and agronomic losses on the product, with negative impact on the economy and a threat to food security [2-3]. Cowpea is a tropical crop of the Fabaceae family, and is almost a staple food for both the poor and the rich households [4-6] reports that cowpea is rich in protein, fat, minerals and vitamins and affordable especially by the low income households and very easy to prepare with high taste profile[7]. About 12.5million hectares of cowpea is cultivated worldwide; yielding well over 3million tones of beans annually. The crop has been described as a 'wonder' crop of Nigeria agriculture [8-9].

At emergencies of insect infestation, farmers and food processors use synthetic chemical insecticides; aldrin/diedrin, chlordane, endrin and DDT to protect stored cowpea [10] Synthetic insecticides are chemicals that are purposely applied to suppress and protect agricultural and industrial products from the damaging action of insects and pests[11-12,10]. Although, synthetic insecticides exhibit high insecticidal potency and good prediction of insecticidal action against the weevil [13-15] they are toxic to the environment [16-19] because they have high persistence at 
the point of application, insecticidal residues have been implicated in food poisoning and related health effects [2021]. In order to avert the problems of synthetic chemical insecticides are being investigated [22-24]. Bioinsecticides are eco-friendly and most of the plants used for their development have been used for food preparation and in folk medicine without reported adverse effect on human health[25,26,24, 10].

Piper guineense is one of the outstanding potential candidate for use in bioinsecticides [27], the presence of phytochemicals like monoterpenic, sesquiterpenes nepetalactone confer the virtue on the plant seed. Bioinsecticides would be preferred to the synthetic counterpart because it is cheap, available, effective, environmentally friendly and renewable [27-29,19,24].

The study used the mixture experimental design to determine the optimum formulation of bioinsecticides fromaqueous, ethanol, and acetone extracts of $P$. guineenseagainst Callosabruchus maculatus.

\section{MATERIALS AND METHODS}

Piper guineense seed was obtained from Utu Ikot Ukpong, Essien Udim Local Government Area of Akwa Ibom State, Nigeria. Young cowpea weevils were obtained from Akwa Ibom State Agricultural Development Programme (AKADEP) Office, Ikot Ekpene.Distilled water, ethanol, acetone were of analytical grade.

\section{Preparation of plant product extracts}

P. guineense was soaked and bruised between the palms to remove the berries, the seeds were separated from the fruit and dried, blended with Super-Master food blender (No.1, Japan) to pass through $300 \mu \mathrm{m}$ sieve. The granulated plant product was divided into 3 groups. Each group was extracted with distilled water, ethanol and acetone under refluxed with reflux system (Model No. 1220, Germany) for 4 hours named, the different extracts were labeled; A, B, and $\mathrm{C}$ and stored in different $100 \mathrm{ml}$ capacity bottles for use

\section{Experimental design: background}

The mixture experimental design is a flavour of response surface experiment in which the characteristics of the mixture is a function of the proportions of each component [30]. These proportional amounts of each ingredient may be measured by weight, volume, and mole ratio. The components in a mixture experimental design assume equations 1 and 2, where the components add up mostly to unity (1 or $100 \%$ ).

$$
\begin{aligned}
& \sum_{j=1}^{n} x j=1=100 \% \\
& \mathrm{Xj}=1.0-\sum_{i=1}^{j-1} x j-\sum_{i=j+1}^{n} x j
\end{aligned}
$$

Thesimplex-lattice flavour of the design consists of equal proportions of $0,1 / 3,2 / 3$, and 1 for common aqueous extract (A), ethanol extract (B) and acetone extract (C) of Piper guineense seed respectively designated by $\{3,3\}$ Design.The design determines the desired performance of pure, binary and centroidblendsin the experiment [31,32]. The simplex-lattice design [33] was used for the experiment, augmented with axial check blends and overall centroid with replication. A layout of the three blends of the design is shown in Table 1.

Table.1: Specification of primary components

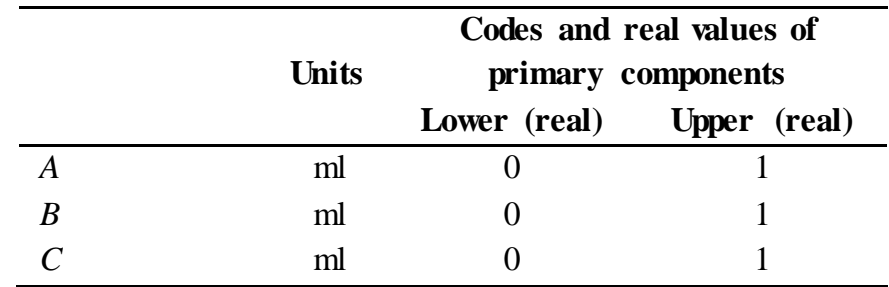

A (aqueous extract), B (ethanol extract) $\mathrm{C}$ (acetone extract) of $P$. guineense

From Table 1 the constraints on the levels of the primary components in the designassume equations $1 \mathrm{a}, 1 \mathrm{~b}$, and $1 \mathrm{c}$ of the plant products.
$0 \%(0 \mathrm{ml}) \leq \mathrm{A}) \leq 1 \%(\mathrm{ml})$
.. (a)
$0 \%(0 \mathrm{ml}) \leq \mathrm{B}) \leq 1 \%(\mathrm{ml})$
... (b)
$0 \%(0 \mathrm{ml}) \leq \mathrm{C}) \leq 1 \%(\mathrm{ml})$
... (c)
Where
$\mathrm{A}+\mathrm{B}+\mathrm{C}=1$ or $100 \%$
$\ldots \quad$ (d) of the

mixture.

The mathematical function in equation 2 existed for each response, $Y_{k}$, in terms of the 3 components.

$Y_{i}=f(A, B, C)$

Where $Y_{i}$ is a dependent variable, $\beta_{\mathrm{i}}, \beta_{\mathrm{ii}}$, and $\beta_{\mathrm{ij}}$ are linear, quadratic, and interactive effects of the independent variables respectively.

\section{Animal assay}

Young weevils were introduced into 14 Petri dishes (totaling 72 in triplicates) containing 100 grains of disinfected cowpea and stored in a laboratory microclimate with average temperature of about $29^{\circ} \mathrm{C}$ and relative humidity of $70 \%$. The plates were inoculated according to the experimental design in Table 1. 
Animal assay was carried out according the method of [27]. Ten (10) eggs of cowpea weevil were introduced into the Petri dishes which contained cowpea samples which were soaked in the different blends of the plant extracts, according to the experimental plan in Table 2. The plates were covered with porous material and set aside in the laboratory. After 49 days, three (3) days after the theoretical life-cycle of the weevil, the Petri dishes were opened, the number of dead insects determined by failure of probed insects to move $\left(\mathrm{Y}_{1}\right)$, and percentage of completely damaged grains determined by the number of holes on the beans $\left(\mathrm{Y}_{2}\right)$ were determined.

\section{RESULTS AND DISCUSSION}

Table 2, shows the standard and natural runs of the experiment, proportions of the extracts; aqueous, ethanol and acetone in each formula, experimental runs 1 to 14 , percentage of dead insects, and cowpea bean damage based on number of holes and weight loss on the cowpea beans.

\begin{tabular}{ccccccc}
\multicolumn{6}{c}{ Table.2: Experimental layout and results from a mixture design } \\
\hline Std & Run & A & B & C & $\begin{array}{c}\text { No. of dead } \\
\text { insects }\end{array}$ & $\begin{array}{c}\text { \% grain } \\
\text { damage by wt } \\
\text { of beans }\end{array}$ \\
\hline 5 & 1 & 0.50 & 0.00 & 0.50 & 75 & 39 \\
3 & 2 & 0.00 & 0.00 & 1.00 & 81 & 49 \\
9 & 3 & 0.17 & 0.67 & 0.17 & 82 & 38 \\
12 & 4 & 0.00 & 1.00 & 0.00 & 59 & 84 \\
6 & 5 & 0.00 & 0.50 & 0.50 & 95 & 32 \\
14 & 6 & 0.50 & 0.50 & 0.00 & 67 & 72 \\
13 & 7 & 0.00 & 0.00 & 1.00 & 78 & 80 \\
10 & 8 & 0.17 & 0.17 & 0.67 & 90 & 31 \\
8 & 9 & 0.67 & 0.17 & 0.17 & 59 & 89 \\
4 & 10 & 0.50 & 0.50 & 0.00 & 48 & 65 \\
1 & 11 & 1.00 & 0.00 & 0.00 & 40 & 89 \\
2 & 12 & 0.00 & 1.00 & 0.00 & 73 & 53 \\
7 & 13 & 0.33 & 0.33 & 0.33 & 87 & 45 \\
11 & 14 & 1.00 & 0.00 & 0.00 & 54 & 91 \\
\hline
\end{tabular}

$\mathrm{Std}=\mathrm{standard}$ run, Run=natural run, $\mathrm{A}=$ aqueous extract, $\mathrm{B}=$ ethanolic extract, $\mathrm{C}=$ acetone extract of $P$. guineenseseed

The general linear model of data obtained from the experiment in Table 3 shows the ANOVA, regression and coefficients of the parameters. The table shows that the model of number of dead insects was significant $(\mathrm{p}<0.05)$ and that the linearity coefficient was significant $(99.31 \%$ and mean of 68.69). the pure blends of the aqueous, ethanol, acetone extracts were significant on the parameter (dead insects) $(p<0.05)$, the binary blends of aqueous/acetone and ethanolic/acetone extracts appeared to be significant $(\mathrm{p}=0.0783$ and $\mathrm{p}=0.0572)$ respectively, while the tertiary blend was not significant.

Table.3: ANOVA, regression analysis, and coefficients of the parameters

\begin{tabular}{|c|c|c|}
\hline Source/Effect & Estimate & p<value \\
\hline Model & & 0.0006 \\
\hline A & 46.34 & 0.0003 \\
\hline B & 66.16 & 0.0001 \\
\hline $\mathrm{C}$ & 79.35 & 0.0001 \\
\hline$A^{*} \mathrm{C}$ & 41.88 & 0.0783 \\
\hline $\mathrm{B}^{*} \mathrm{C}$ & 137.61 & 0.0572 \\
\hline$A * B * C$ & NS & NS \\
\hline
\end{tabular}


The predictive model of dead insects is as follows:

Number of dead insects $=46.34 \mathrm{~A}+66.16 \mathrm{~B}+79.35 \mathrm{C}+$

$41.88 \mathrm{AxC}+137.61 \mathrm{BxC} \ldots(3)$

The table further revealed that parameter estimate of acetone extract shows higher value of 79.55 than ethanol (66.16) and aqueous extract (46.34) respectively, it show that single blend of acetone extract may process higher insecticidal potency than ethanolic and aqueous blends. The cross product of aqueous/acetone $(\mathrm{A} * \mathrm{C})$ and ethanol/acetone $\left(B^{*} \mathrm{C}\right)$ appeared to be significant $(\mathrm{p}<0.0788$, and $\mathrm{p}<0.0572)$, indicated that the interaction of the blends was antagonistic on the model.Equation 3 shows the contribution of the estimates to the model which could be manipulated to produce bioinsecticides of a required insecticidal potency. Response surface plot (Figure 3) shows that higher insecticidal potency increased with the higher proportion of acetone extract, and lower proportion of aqueous and ethanolic extracts of $P$. guineense seed extracts.

\section{Percentage damage on cowpea bean}

Table 4 shows the following analysis of variance (ANOVA) results and reveals the predictive estimates for a quadratic polynomial fit to the data. The table shows that the model of parameter was significant $(\mathrm{p}<0.05)$ showing an adequate quadratic polynomial fit $\left(\mathrm{R}^{2}=97.86 \%\right)$ for the predictive model.

Table.3: ANOVA, regression analysis, and coefficients of the parameters for beans damage.

\begin{tabular}{ccc}
\hline Source/Effect & Estimate & p<value \\
\hline Model & & 0.0001 \\
A & 50.00 & 0.0001 \\
B & 66.60 & 0.0004 \\
C & 82.68 & 0.0017 \\
A*B & -40.66 & 0.4448 \\
A*C & -142.70 & 0.0649 \\
B*C & -489.29 & 0.0375 \\
\hline $\mathrm{R}^{2}=0.9786$ & &
\end{tabular}

Mean $=63.46$

The predictive model of damage to the cowpea bean is as follows:

Percentage damage to cowpea bean $=50 \mathrm{~A}+66.60 \mathrm{~B}+$

$$
82.68 \mathrm{C}-40.66 \mathrm{AB}-142.70 \mathrm{AC}-489.29 \quad \ldots \quad 4
$$

The pure blends of aqueous, ethanolic and acetone were significant on the parameter $(\mathrm{p}<0.05)$. The cross product of ethanolic/acetone extracts was significant to the parameter $(\mathrm{p}<0.05)$ aqueous/ethanolic appeared to be significant. The table further reveals that the parameter estimates of acetone extract shows higher value of 82.68 than ethanol (66.60) and aqueous extract (50.00) respectively, it show that single blend of acetone extract may exhibited higher insecticidal potency than ethanolic and aqueous blends of the extracts. The cross product of aqueous/acetone $\left(\mathrm{B}^{*} \mathrm{C}\right)$ and ethanol/acetone (AC) appeared to be significant $(\mathrm{p}<0.0375$, and $\mathrm{p}<0.0649)$ respectively, indicating that the interaction of the blends was antagonistic on the model. 


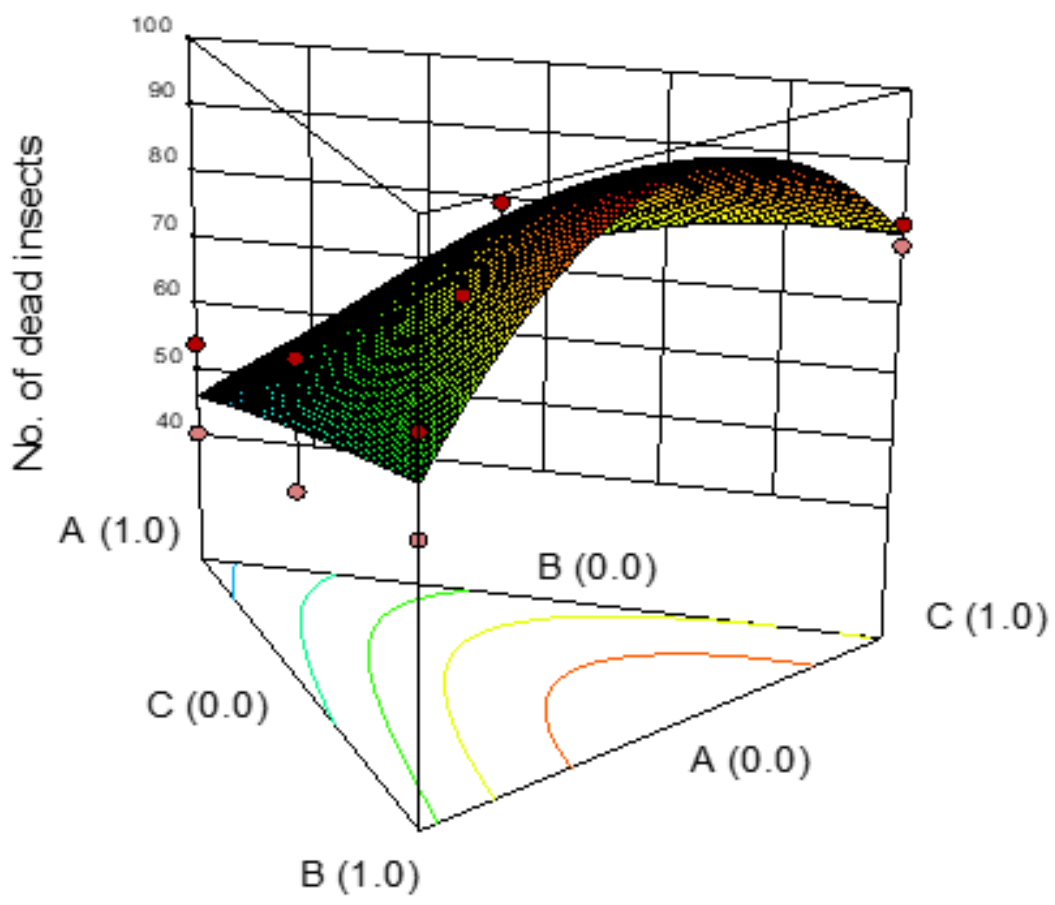

Equation 4 shows the weight of the estimates on the model which could be manipulated to protect cowpea from damage of $C$. maculatus. Response surface plot (Figure 4) shows that bean seed protection increased with the proportion of acetone extract in the formulation.

\section{Optimization}

Optimization analyses of data from the experiment showed that $0.09,0.437$, and 0.473 proportions of aqueous, ethanolic, acetone extracts of Piper guineense seed respectively produced $95 \%$ and $31.13 \%$ of dead insect and bean damage respectively at a desirability level of 76.90 .<smiles>CC(=O)OCC[N+](C)(C)C</smiles>

Acetylcholine

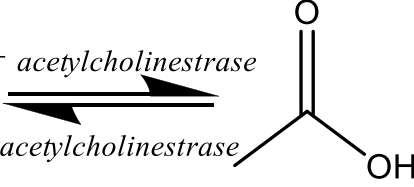

Acetic acid<smiles>C[N+](C)(C)CCO</smiles>

choline

Fig.5: Degradation of acetylcholine molecule

The enzyme acetylcholinesterase converts acetylcholine into the inactive metabolitescholine and acetate, Equation 5. This enzyme is abundant in the synaptic cleft, and its role in rapidly clearing free acetylcholine from the synapse is essential for proper muscle function. Certain neurotoxins in insecticides work by inhibiting acetylcholinesterase, thus leading to excess acetylcholine at the neuromuscular junction, causing paralys is of the muscles needed for breathing and stopping the beating of the heart. Failure to synthesize the Ach leads to inactivity and dead of the organism, in man and other larger animals the break synthes is of the chemical is reversible [36].

Observations in our study suggest that aqueous, ethanol, and acetone extracts of Piper guineensecould 
interrupt the function of acetylcholesterase in insect from normal living and reduce damage to stored product [37], it was noticed that the pure blends of the ethanolic and acetone were more potent than the binary and ternary blends. This observation was similar to the one reported by [38] and attributed to the relative extraction coefficient of the active components from $P$. guineense. For instance pure blends of acetone extract of $P$. guineenseshowed higher percentage of dead insects in all cases than the ethanolic extract, while the aqueaaous extract showed lower insecticidal potency on the animal modes. This could be attributed to the incomplete extraction of the active ingredients from the plant materials, also the combination of the extracts with the aqueous extract blends showed antagonistic effects on the parameter than those treated with the pure blends of ethanol and acetone alone. Therefore grain damage was low in units treated with ethanolic and acetone extracts of $P$. guineense, the observation was reported by $[39,1]$.

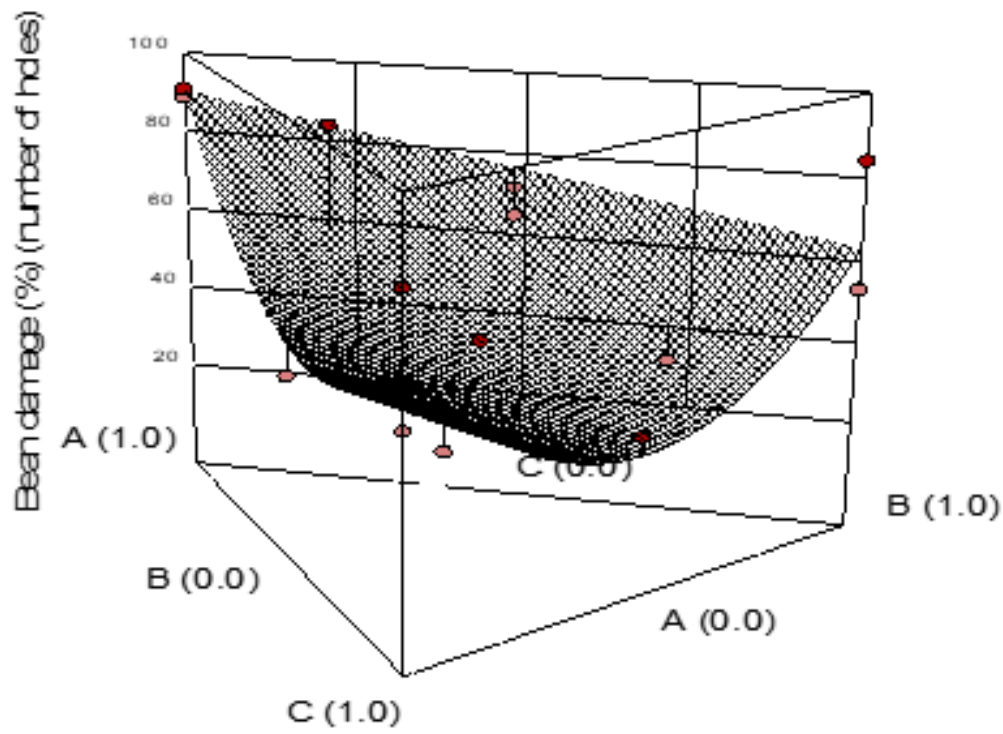

Fig.2: Response surface plot of plant extracts against bean damage by number of holes

\section{CONCLUSION}

The result of the work showed that the aqueous, ethanol, and acetone extracts of Piper guineenseseed could protectblack eye cowpea against attack of $C$. maculatusunder the conditions of the experiment.In the study, pure blends of acetone and ethanol were more potent in that order than aqueous extract. The binary blend of ethanolic and acetone and aqueous showed antagonismin response. Formulation of blends of the extracts could be useful for short period of storage.Longer period of storage and replacement of some safe insecticides with the botanicals should be investigated.

\section{REFERENCES}

[1] Chomchalow N (2003) Protection of stored products with special reference to Thailand. Au J. T. 7(1): 3147.

[2] Jacobson MDK, Reed MM, Crystal DSM and Sodastorm EL (1978). Chemistry and biological activity of insect feeding deterrents. Entomologia Exp. Appl. 24:248-257.
[3] Jimenez A, Romojaro F, Gomez JM, Lianos MR, Sevilla F (2003) Antioxidant systems and their relationship with the response of pepper fruits to storage at $20^{\circ} \mathrm{C}$. Agric. Food Chem. 51(21): 6293-9.

[4] Oyenuga VA (1968). Nigerian foods and feedstuffs. Ibadan University Press, p.99

[5] Olatunde AF (1989). Maize utilization and nutrition: In Food crop production, utilization and nutrition. (eds. B. N. Mbah, \& D. O. Nnanyelugo) Department of Home Sciences and Nutrition of Nigeria, Nsukka. pp 96-110.

[6] Konan KC, Fofana I, Coulibaly A, Koffi NE, Chatigre O, Biego GHM (2016). Optimization of Storage Methods of Cowpea (Vigna Unguiculata L. Walp) bagged Pics containing biopesticide (Lippia Multiflora) by Central composite Experimental design in Cote D'ivoire. International Journal of Environmental \& Agriculture Research (IJOEAR) 2(7): 1-11.

[7] Baidoo PK, Mochiah MB, Owusu-Akywa M. (2010) The effect of time of Harvest on the Damage Caused by the Cowpea Weevil Callosobruchus maculatus (Fab.) 
(Callos obruchus: Bruchidae) Journal of Stored Products and Postharvest Research, 1(3), pp. 24-28.

[8] Ofuya TI (2003) Beans, insects and man. Inaugural Lecture Series 35. The Federal University of Technology, Akure, Nigeria. 45pp.

[9] Longe OO (2016) Evaluating the efficacy of some plant powders on the bean weevil [Callosobruchus maculatus (Fabricius) (Coleoptera: bruchidae)] affecting stored cowpea seeds (Vigna unguiculata). Asian Journal of Science and Technology 7(2): 2486-2490.

[10] Waghunde RR, Shelake RM, Sabalpara AN (2016) Trichoderma: A significant fungus for agriculture and environment: A Review. African Journal of Agricultural Research, 11(22): 1952-1965.

[11] Birch ANE, (2011) How agro-ecological research helps to address food security issues under new IPM and pesticide reduction policies for global crop production systems. J Exp Bot. 62:3251-3261.

[12] Srivastava KP, Dhaliwal GS (2010) A Textbook of Applied Entomology. Concepts in Pest Management. Kalyani Publishers, New Delhi, 1.

[13] Sarwar M (2015a). The Killer Chemicals as Controller of Agriculture Insect Pests: The Conventional Insecticides. International Journal of Chemical and Biomolecular Science, 1 (3): 141-147.

[14] Sarwar M (2015b). Microbial Insecticides-An Ecofriendly Effective Line of Attack for Insect Pests Management. International Journal of Engineering and Advanced Research Technology, 1 (2): 4-9.

[15] Sarwar, M. (2016) Families of Common Synthetic Agrochemicals Designed to Target Insect Pests or Vectors in Landscapes and Households Chemistry: a Review, Chemistry Research Journal, 1(3):7-13.

[16] FAO/WHO (1977). Pesticide residues food quality: FAO plant production and protection Paper 10 Sup.

[17] Essam Abdel-Salam Shaalan, Deon Vahid Canyon, Mohamed Wagdy, Faried Younes, Hoda Abdel-Wahab, and Abdel-Hamid Mansour (2005) Aedes aegypti and Culex annulirostris mosquitoes. Journal of Vector Ecology, 30 (2): 284-288.

[18] Coul O, Walia S (2009) Comparing impacts of plant extracts and pure allelochemicals and implications for pest control. CAB Review: Perspectives in agriculture, veterinary Science, Nutrition and Natural Resources. 4. N. 049.

[19] Chaturvedi M, Sharma C, Chaturvedi M (2013) Effects of Pesticides on Human Beings and Farm Animals: A Case Study. Academy for Environment and Life Sciences.
[20] Sonchieu J, Ngas soum M B, Tchatchueng JB, Ashutosh KS Laxman PS (2013) Contamination of cowpea and by-products by organophosphorous pesticide residues in Ngaoundere markets: dietary risk estimation and degradation study. African Journal of Food Science, 7(5): 92-102.

[21] Zhu F, Lavine L, O’Neal S, Lavine M, Foss C, Walsh D (2016) Insecticide Resistance and Management Strategies in Urban Ecosystems: A Review. Insects, pp $1-26$.

[22] Schmitterer $H$ and Ascher KRS. (1987) Natural pesticides from the neem trees $A$ indica,A. Juss. and other tropical plants. Proc. 2nd Int. Neem Conf; Rauischholzhausen, 25-28 May 1983. GT2, Eschborn; 587.

[23] Opender K, Suresh W, Dhaliwal GS (2008) Essential Oils as Green Pesticides: Potential and Constraints. Biopestic. Int. 4(1): 63-84 (2008).

[24] Nnamonu LA and Onekutu, A. (2015) Green pesticides in Nigeria: an overview. Journal of Biology, Agriculture and healthcare. Vol. 5.

[25] Baier AH, Webster BD, (1992). Control of Acanthoscelides obtectus Say (Coleoptera: Bruchidae) in Phaseolus vulgaris L. seed stored on small farms. Evaluation of damage. J. Stored Prod Res 28: 289-293.

[26] Al-Zaidi AA, Elhag EA, Al-Otaibi SH, Baig MB, (2011) Negative effects of pesticides on the environment and the farmer's awareness in Saudi Arabia: a case study. J Anim Plant Sci 21:605-611.

[27] Ojimelukwe PC (2002). Potentials of Xylopia aethopica for short term protection of cowpea (var. IT-81D-975) seeds in Nigeria. Nigerian Agric. Journal. 3139-48

[28] Aktar MW, Sengupta D, Showdhury A (2009) Impact of insecticides use in agriculture: benefits and hazards. Journal of Interdiscip Toxicol. 2(1): 1-12.

[29] Echereobia CO, Okerere1 CS, and Emeaso KC (2010). Determination of repellence potentials of some aqueous plant extracts against okra flea beetles Podagrica uniforma. Journal of Biopesticides 3(2): 505 - 507.

[30] Bondari K. (1999). Interactions in entomology: multiple comparisons and statistical interactions in entomological experimentation. Journal of Entomological Science 34:57-71.

[31] Box GEP and Behnken DW (1960) Some New Three Level Design for the Study of Quantitative Variable, Technometrics, 2 (4): 445-475.

[32] Cornel JA (2002) Experiment with mixtures: Models, and the analysis of mixture data, 3rd Edition, 680 pages, John Wiley \& Sons, Inc. USA. 
[33] Scheffe H (1963), Simplex lattice design for experiment with mixture. Journal of Royal Statistical Society, Series B 28: 235-263.

[34] Zhu-Salzman K, Koiwa H, Salzman RA, Shade RE, Ahn JE (2003) Cowpea bruchid Callosobruchus maculatus uses a three-component strategy to overcome a plant defensive cysteine protease inhibitor Insect Molecular Biology, 12(2), 135-145.

[35] Shadashiva CT, Naidoo TR, Naido Y, Naido G (2013) Antioxidant and acetylcholinesterase activities of three species of the family Lamiaceae. Bangladesh Journal of Botany, 43(3):335-339.

[36] ICCBS (2008). International Centre for Chemical and Biological Sciences. Scientific Evaluation and Product Development Series. Pp 1-2.

[37] Dubey, S. C., Bhawana, B. and Ashok, K (2008). Current status of plants products as botanical pesticides in storage pest management. Journal of Biopesticides 1(2):182-186.

[38] Arong GA and Usua EJ, (2006) Comparative development of cowpea bruchid, (Callosobruchus maculatus (F.) (Coleptera: Bruchidae) on pods and seeds of some cowpea cultivars (Vigna Unguiculata) .Global Journal of Pure and Applied Sciences, Vol. 12, No. 1, pp 35-40.

[39] Asawalam, E. F. and Emosairue, S.O. (2006). Comparative efficacy of Piper quineense (Schum and Thonn) and Pirimphosmethyl on Sitophylus zeamais (Motsc) Tropical and Subtropical Agroecosystems 6(3):143-148. 